\title{
Increased ventilatory lung stretch alters the effect of soluble guanylyl cyclase-derived cGMP on endothelial barrier function in isolated mouse lungs
}

\author{
EP Schmidt ${ }^{1}$, AJ Gonzales ${ }^{1}$, LE Servinsky ${ }^{1}$, JM Dodd- ${ }^{2}$ and David B Pearse*1
}

Address: ${ }^{1}$ Division of Pulmonary and Critical Care Medicine, Johns Hopkins University, Baltimore, MD, USA and ${ }^{2}$ Department of Anesthesiology and Critical Care, Johns Hopkins University, Baltimore, MD, USA

Email: David B Pearse* - dpearse@jhmi.edu

* Corresponding author

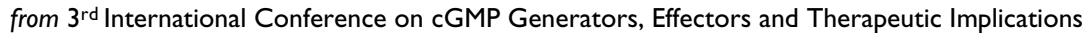

Dresden, Germany. I5-17 June 2007

Published: 25 July 2007

BMC Pharmacology 2007, 7(Suppl I):P5I doi:I0.1186/I47I-22I0-7-SI-P5 I

This abstract is available from: http://www.biomedcentral.com//47/-22 I0/7/SI/P5 I

(C) 2007 Schmidt et al; licensee BioMed Central Ltd.

\section{Background}

Ventilator-induced lung injury (VILI) increases lung endothelial permeability. Lung endothelial nitric oxide (NO) generation contributed to this increased permeability in an intact mouse model of VILI [1]. NO stimulates endothelial soluble guanylyl cyclase (sGC) to produce cGMP. The effect of cGMP on endothelial permeability is controversial [2]. We sought to determine 1) if endothelial cGMP is generated in VILI and 2) if changes in endothelial cGMP modulate VILI-induced endothelial barrier dysfunction.

\section{Methods}

Isolated C57BL6 mouse lungs ( $\mathrm{n}=2-6$ per group) were ventilated with $21 \% \mathrm{O}_{2}, 5 \% \mathrm{CO}_{2}$ at a rate of 120 breaths/ minute at tidal volumes (TV) of $0,6,15$ or $20 \mathrm{ml} / \mathrm{kg}$ and perfused with a constant flow of physiologic buffer (with $3 \%$ albumin). We measured serial perfusate cGMP concentrations (with IBMX) and assessed permeability by the filtration coefficient (Kf; without IBMX). The sGC inhibitor ODQ and the NO-independent sGC activator Bay 412272 were used to manipulate sGC activity; atrial natriuretic peptide (ANP) was used to stimulate particulate GC (pGC) activity.

\section{Results}

By 80 min of ventilation, perfusate cGMP increased as a function of time and TV with a maximal increase of 24- fold occurring with $15 \mathrm{ml} / \mathrm{kg} \mathrm{TV}$. Kf was unchanged with 6 and $15 \mathrm{ml} / \mathrm{kg} \mathrm{TV}(\mathrm{Kf}=0.8 \pm 0.3 \mathrm{ml} / \mathrm{min} / \mathrm{mmHg} / 100 \mathrm{~g}$ ) but was increased 6 -fold with $20 \mathrm{ml} / \mathrm{kg}$ TV indicating VILI. ODQ attenuated cGMP production and eliminated the increased $\mathrm{Kf}$ in $20 \mathrm{ml} / \mathrm{kg}$ lungs $(\mathrm{Kf}=0.8 \pm 0.3 \mathrm{ml} / \mathrm{min} /$ $\mathrm{mmHg} / 100 \mathrm{~g}$ ) suggesting sGC/cGMP-mediated barrier dysfunction. Consistent with this, Bay 41-2272 (1.5 $\mu \mathrm{M})$ administered at $40 \mathrm{~min}$ of perfusion further increased perfusate cGMP and markedly exacerbated $\mathrm{Kf}$ in $15 \mathrm{ml} / \mathrm{kg}$ lungs by 9-fold but neither the low $\mathrm{Kf}$ in $6 \mathrm{ml} / \mathrm{kg}$ TV lungs nor high $\mathrm{Kf}$ in $20 \mathrm{ml} / \mathrm{kg}$ TV lungs were affected. The adverse Bay 41-2272 effects on cGMP and Kf could be prevented by ODQ pretreatment ruling out a nonspecific drug effect. Underscoring the apparent injurious interaction of sGC activity and lung stretch, the administration of the same Bay 41-2272 dose $10 \mathrm{~min}$ before increasing TV to $15 \mathrm{ml} / \mathrm{kg}$ had no effect on Kf after $80 \mathrm{~min}$ at this TV (Kf $=1.2 \pm 0.5 \mathrm{ml} / \mathrm{min} / \mathrm{mmHg} / 100 \mathrm{~g}$ ) compared to diluent control. Moreover, these effects were specific to sGC, because pGC activation with atrial natriuretic peptide (ANP) did not affect Kf whether administered before or after the onset of injurious ventilation.

\section{Conclusion}

These data suggest that endogenous lung endothelial cGMP increases from sGC stimulation in VILI and contributes to VILI-induced endothelial barrier dysfunction. The mechanism of this injurious effect appears to require 
an interaction between sGC and lung stretch because 1) an increased level of stretch for a critical period of time was required before sGC activation resulted in endothelial barrier dysfunction and 2) pGC stimulation had no effect. Based on these data we speculate that ventilatory stretch may shift the subcellular location of endothelial sGC to a compartment where cGMP production increases endothelial permeability.

\section{References}

I. Peng X, Abdulnour RE, Sammani S, Ma SF, Han EJ, Hasan EJ, Tuder R, Garcia JG, Hassoun PM: Inducible nitric oxide synthase contributes to ventilator-induced lung injury. Am J Respir Crit Care Med 2005, I 72:470-479.

2. Moldobaeva A, Welsh-Servinsky LE, Shimoda LA, Stephens RS, Verin $A D$, Tuder RM, Pearse DB: Role of protein kinase $\mathbf{G}$ in barrierprotective effects of cGMP in human pulmonary artery endothelial cells. Am J Physiol Lung Cell Mol Physiol 2006, 290:L919-L930.

Publish with Bio Med Central and every scientist can read your work free of charge

"BioMed Central will be the most significant development for disseminating the results of biomedical research in our lifetime. " Sir Paul Nurse, Cancer Research UK

Your research papers will be:

- available free of charge to the entire biomedical community

- peer reviewed and published immediately upon acceptance

- cited in PubMed and archived on PubMed Central

- yours - you keep the copyright

Submit your manuscript here:

http://www.biomedcentral.com/info/publishing_adv.asp 